\title{
Oberto Marrama
}

Université du Québec à Trois-Rivières / University of Groningen

\section{CONFLICTS OF THE SOUL AND MIND-BODY INTERACTION IN DESCARTES'S PASSIONS OF THE SOUL}

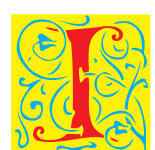

$\mathrm{n}$ the following paper, I aim to provide a clear account of Descartes' explanation of akratic behaviour in his Passions of the Soul. ${ }^{1}$ The analysis of Descartes' arguments will give me the occasion to remark on some aspects, which I regard as seminal for the understanding of his controversial theory of mind-body interaction through the pineal gland. ${ }^{2}$ In particular, I will focus on Descartes' insights into his theory of the "Natural Institution" and the role of the body as the effective place where the "conflicts of the soul" are determined to occur.

In the first section I will briefly recall the Platonic theory of the partitioning of the soul, presenting it - in agreement with a long interpretive tradition-as Plato's answer to the philosophical problem of akratic behaviour. In the second, I will introduce Descartes' arguments in favour of the unity

1 A reduced version of this paper was presented on July 13, 2016, at the University of Lodz, within the frame of the 2016 ISSEI Conference. The research was supported by the Fonds de recherche du Québec - Société et culture (FRQSC), whereas the participation to the conference was generously supported by the Décanat des études of the UQTR. I am grateful to Syliane Malinowski-Charles, who organised the panel "The Question of Life in 17th-Century Mechanism," for her useful comments on previous versions of this paper. All English quotations of Descartes's works are from Cottingham, Stoothoff, and Murdoch 1984 (hereafter abbreviated as "CSM"). English quotations of Descartes's correspondence are from Cottingham et al. 1991 (abbreviated as "CSMK"). The abbreviation "AT" refers to Adam and Tannery 1897-1813.

2 In a recent article, Lisa Shapiro correctly points out the importance of Descartes's Passions of the Soul with regard to this topic: "The account of the passions, or emotions, developed in the Passions of the Soul opens new lines of approach to the long-standing MindBody Problem, as well as fuels a new line of inquiry into Descartes's and other rationalists' ethics" (Shapiro 2006: 268). 
of the soul, and identify their possible polemical targets. In the third, I will analyse Descartes' treatment of the notion of "conflicts of the soul" and his characterisation of the role of the body in determining the origin of these conflicts. In the following section, I will analyse Descartes's account of mind-body interaction, focusing on the autonomy of the body, its union with the soul, and the activity of the soul. I will complete this analysis by considering Descartes' remarks on the "natural institution" of a correspondence between psychological and physiological states. These considerations will clarify Descartes' references to an indirect activity of the mind upon the body, and of the body upon the mind, and will help understand the means by which Descartes maintains the existence of akratic behaviour and the unity of the soul at the one and the same time.

\section{The partitioning of the soul on Plato's account}

According to a traditional interpretation of the Platonic account of the human soul, the coexistence of different and conflicting parts of the soul explains why, in our common everyday experience, we often feel torn by competing desires or feel our will overwhelmed by compelling inclinations, passions, and drives that oppose our free judgments and resolutions. ${ }^{3}$ In Phaedrus Plato writes:

We must realize that each of us is ruled by two principles which we follow wherever they lead: one is our inborn desire for pleasures, the other is our acquired judgment that pursues what is best. Sometimes these two are in agreement; but there are times when they quarrel inside us, and then sometimes one of them gains control, sometimes the other. ${ }^{4}$

In a later passage within the same dialogue, Plato puts forward his famous metaphor of the human soul as resembling a flying chariot, which is pulled in diffe-

3 See, for example, Burnyeat 1976; Moline 1978 and 1981: 53-78; Annas 1981: 123-146; Irwin 1995: 219-222; and Bobonich 2001: 204-206. See also Frede 1992; and Miller 1999: 100, who understand Plato's theory of the multi-parted soul as a reply and a tentative solution to the problems generated by Socrates's ethical intellectualism and the relevant underlying psychology, which-as they are exposed, for instance, in Plato's Protagoras - implied, amongst other things, a denial of akratic conduct.

${ }^{4}$ Plato, Phaedrus, 237d-238a, Nehamas and Woodroof, 1997, 516-517. 
rent directions by two different winged horses, and is led by a single charioteer. He writes:

Here is what we must say about [the] structure [of the human soul]. [...] Let us then liken the soul to the natural union of a team of winged horses and their charioteer. [...] To begin with, our driver is in charge of a pair of horses; second, one of his horses is beautiful and good and from stock of the same sort, while the other is the opposite and has the opposite sort of bloodline. This means that chariot-driving in our case is inevitably a painfully difficult business. ${ }^{5}$

In the wake of these paragraphs taken from Plato's Phaedrus, one might also be tempted to recall Plato's most famous tripartition of the soul, as exposed by means of Socrates' words in the Fourth Book of the Republic - although, in that context, the description of the human soul and of its parts was ultimately meant to support Plato's theory of the just polis. ${ }^{6}$ Hence, by recurring to a political metaphor, Plato writes:

Injustice [in a man] must be a kind of civil war between the three parts [of the soul], a meddling and doing of another's work, a rebellion by some part against the whole soul in order to rule it inappropriately. ${ }^{7}$

As noted above, according to the most common reading of these passages, Plato's peculiar way of partitioning the human soul into conflicting faculties or parts was the kind of explanation he provided to justify what we may call, after Aristotle, the phenomenon of the akratic conduct, that is, a traditional philosophical conundrum which is also sometimes addressed as the problem of the weakness of the will.

Now, several questions could be raised, concerning this way of reading Plato's remarks on the nature of the human soul. For instance, whether the soul is to be regarded as essentially divided into parts-that is also to say, whether the soul can still exist and be considered the same without one or more of these parts being actively present in it; whether these parts can exist

5 Plato, Phaedrus, 246a-b, Nehamas and Woodroof, 1997, 524. See also the description Plato provides of the two horses, in Phaedrus, 253b-e, Nehamas and Woodroof, 1997, 531.

6 See Plato, Republic, 434d-445c, Grube and Reeve, 1997, 1066-1076.

7 Plato, Republic, 444b, Grube and Reeve, 1997, 1075. See also Plato, Republic, 586e, Grube and Reeve, 1997, 1194. 
separately from each other, and constitute therefore separate autonomous souls; or else, whether these distinct faculties, or parts of the soul, are actually two or three, according to Plato. ${ }^{8}$ All these problematic points notwithstanding, in the present circumstances I am willing to take the opinion shared by the majority of interpreters as valid, that is, that according to Plato the human soul is effectively divided into conflicting parts, and these conflicts—or this "civil war," to retain Plato's metaphor-occurring between different parts of the soul are meant to explain what we may call akrasia, or the weakness of our will. I am willing to do so, for it seems to me that this was also Descartes' take on Plato's psychology.

\section{The unity of the soul on Descartes' account}

As a matter of fact, Article 47 of Descartes's Passions of the Soul directly tackles this commonly accepted Platonic viewpoint on the nature of the soul and on the origin of akratic behaviour, in order to confute it. The title of the article suggests as much: "On what are the conflicts that are usually supposed to occur between the lower part and the higher part of the soul." Descartes' following explanation confirms it:

All the conflicts usually supposed to occur between the lower part of the soul, which we call "sensitive," and the higher or "rational" part of the soul—or between the natural appetites and the will—consist simply in the opposition between the movements which the body (by means of its spirits) and the soul (by means of its will) tend to produce at the same time in the gland. For there is within us but one soul, and this soul has within it no diversity of parts: it is at once sensitive and rational too, and all its appetites are volitions. It is an error to identify the different functions of the soul with persons who play different, usually mutually opposed roles_-an error which arises simply from our failure to distinguish properly the functions of the soul from those of the body. It is to the body alone that we should attribute everything that can be observed in us to oppose our reason. ${ }^{10}$

8 The reader interested in deepening these points may refer to Shields 2007 and Shields 2014 (2010). These two articles question the commonly accepted reading of Plato's psychology I have just exposed.

9 CSM I, 345 / AT XI, 364.

${ }^{10}$ CSM I, 345-346 / AT XI, 364-365. 
Other arguments in favour of the essential unity of the soul, and against any division of the soul into different parts, can be found in several other places within Descartes' works. Similar to this case, they are often accompanied by considerations regarding the radical distinction between the mind and the body, and their absolute heterogeneity. A very long and articulate passage is in the Twelfth of Descartes' Rules for the Direction of the Mind, ${ }^{11}$ whereas in the Sixth Meditation we may read:

There is a great difference between the mind and the body, inasmuch as the body is by its very nature always divisible, while the mind is utterly indivisible. For when I consider the mind, or myself in so far as I am merely a thinking thing, I am unable to distinguish any parts within myself; I understand myself to be something quite single and whole. ${ }^{12}$

Now, in the light of these passages, a careful reader may object that the main polemical target of Descartes' arguments in favour of the unity of the soul could have rather been the traditional Aristotelian scholastic view, according to which the different faculties or functions ascribable to an individual human soul were, in fact, "really distinct from each other and from the soul itself." ${ }^{13}$ This is, to cite a notable example, Marleen Rozemond's point of view, when she writes:

In denying that the faculties of the soul are parts of the soul, and really distinct from it, Descartes is rejecting a long tradition in Aristotelian scholasticism of seeing the human soul as ontologically complex in the sense of containing really distinct parts. On a view often referred to as the "unitarian view," found in Suárez and widely attributed within scholasticism to Aquinas, a human being has a single soul, but its faculties are really distinct from each other and from the soul itself. [...] Insofar as Descartes's point is to reject the idea that the faculties of the soul are really distinct from it[, it] really means that he is taking a stance within a scholastic debate. ${ }^{14}$

11 CSM I, 42 / AT X, 415.

12 CSM II, 59 / AT VII, 85-86. I emended the CSM translation of the Latin word integram, by substituting the English term "complete" with "whole," as suggested by M. Rozemond, "The Faces of Simplicity in Descartes's Soul," Partitioning the Soul: Debates from Plato to Leibniz, ed. K. Corcilius and D. Perler, Berlin/Boston: Walter de Gruyter, 2014, 221, n. 6.

13 M. Rozemond, "The Faces of Simplicity in Descartes's Soul”..., 230.

${ }^{14}$ Ibidem. It is to be noted, however, that Rozemond mainly focuses her analysis on the argument in favour of the unity of the soul that Descartes exposed in his Sixth and Second Meditations. On the other hand, D'Arcy 1996, 246, maintains that the concept of "conflicts of the soul," used by Descartes, is a reference to the Platonic tradition of thought. 
Along with the scholastic "unitarian view," Rozemond also mentions another possible target of Descartes' arguments: the so-called "pluralist view," according to which "within a human being there are at least two really distinct substantial forms or souls." ${ }^{15}$ An advocate of this view was Ockham, who, "while rejecting the idea that the faculties are really distinct from the soul, held that a human being contains a sensitive and an intellectual soul." 16

Now, whether Descartes had in mind Plato's theory of the soul when he was arguing in favour of the unity of the soul, or rather Aquinas', or Suárez's, or else Ockam's view, that does not change the terms of the problem I would like to discuss here. Indeed, as Rozemond herself acknowledges, the problem of finding a consistent explanation of the peculiar phenomenon we regard as the akratic behaviour, remains the same. In a somewhat naïve way, we are all aware that our desires may occur to clash with our best judgments, and that they sometimes seem to prevent us from acting according to the pronouncements of our reason. How do we explain, then, what we perceive as a kind of psychological conflict happening entirely within our soul, without disrupting the singularity of the individual soul itself? As Rozemond writes:

We might feel some inclination in the direction of more ontological complexity when reminded of the problem of psychic conflict: how should we understand a conflict between our will and some rebellious appetite? Do we need parts of the soul in some sense to address that question, either different souls or really distinct faculties? ${ }^{17}$

Now, not only-I argue-does this question retain all its validity; as a matter of fact, it becomes much more pressing in the case of a philosopher such as Descartes, who, as we have just seen, rejects the traditional view that the human soul may be either multiple or composed by different parts. Therefore, in the following sections, I plan to unfold Descartes' original answer to the problem of akrasia. Given the nature of Descartes' arguments, I believe that such explanation could be of some help, in order to better understand Descartes' controversial account of the relationship and interaction between the human mind and body.

15 Rozemond 2014, 230.

16 Ibidem.

17 Ibidem, 232. 


\section{Conflicts of the soul and conflicts in the body}

In the aforementioned Article 47 of the Passions of the Soul, Descartes undertakes to debunk the theories which affirm the existence of conflicts between different parts of the soul. As we have seen, Descartes affirms the essential unity of our soul. He firmly denies that there may exist different parts in it, or that there may exist different kinds of souls in us, corresponding to unique faculties or conflicting functions. As a consequence thereof, he rejects the existence of any psychological conflict between different parts of the soul, or between different souls pertaining to a single individual: "there is within us but one soul," Descartes says, "and this soul has within it no diversity of parts." How can Descartes justify this claim, however, once presented with the evidence of the phenomenon of a self-aware akratic conduct?

As we shall see, Descartes does not deny the existence of self-aware akratic behaviour in humans. Nor does he deny the possibility of accounting for a kind of weakness of the will. The psychological conflicts that the Platonic and the scholastic "unitarian" traditions of thought ascribed to different parts, functions, or faculties existing within a single soul, and that Ockam and the "pluralist" tradition ascribed to different souls, are in fact to be understood, according to Descartes, as conflicts which sometimes occur between the free activity of the soul — of which we are conscious and masters — and the autonomous functioning of the body_ of which we are aware in our mind, yet do not fully control. To be more precise, Descartes goes as far as to suggest that what is commonly felt and regarded as a merely psychological conflict is rather the result of conflicts which effectively take place in our body alone.

At the beginning of Article 47, Descartes describes what we perceive as conflicts in our soul as the result of opposing forces, acting at the same time upon a precise part of our body—that is, upon our pineal gland. ${ }^{18}$ According to Descartes, the pineal gland is, on the one hand, the physiological origin and end of all voluntary and spontaneous movements of our body ${ }^{19}$ and, on the other hand, "the principal seat of the soul," ${ }^{20}$ or the place in the body "where

18 All these conflicts consisting simply, in Descartes's words, in "the opposition between the movements which the body (by means of its spirits) and the soul (by means of its will) tend to produce at the same time in the gland" (CSM I, 345-346 / AT XI, 364-365).

19 CSM I, 340 / AT XI, 352. See also the Article 34 of Descartes' Passions of the Soul (CSM I, 341 / AT XI, 354-355).

20 CSM I, 340 / AT XI, 352. 
the soul exercises its functions more particularly than in the other parts of the body." ${ }^{21}$ Therefore, Descartes argues, what we call conflicts in our soul are rather events which happen within a physiological framework..$^{22}$ They are physiological events of which we nevertheless perceive the effects in our mind, insofar as the moving of our pineal gland transmits an image of them to our mind. Nonetheless, Descartes maintains, we commonly believe them to be the other way around, purely psychological events—conflicts between reason and passions, as it were-, for we clearly feel in our soul the psychological effects of certain bodily dispositions that stand in the way of our free will of judging and acting, without being able to know, however, by which means our bodily dispositions actually constrain our thoughts. Since we cannot fail to feel these effects in our soul, and since they seem to occur against our will, we generally address these perceptions as "passions" in our soul. As Descartes writes in Article 26 of the Passions of the Soul:

We cannot be misled [...] regarding the passions, in that they are so close and so internal to our soul that it cannot possibly feel them unless they are truly as it feels them to be. [...] Even if we are asleep and dreaming, we cannot feel sad, or moved by any other passion, unless the soul truly has this passion within it. ${ }^{23}$

However, Descartes also claims, we do not know the real physiological causes that produce those dispositions in our body, along with the corresponding mental states in our mind:

${ }^{21}$ CSM I, 340 / AT XI, 351.

${ }^{22}$ Byron Williston perfectly summarises the whole point, when he writes: "Descartes has shifted the locus of conflict from the soul to the pineal gland" (Williston 1999: 48). This consideration, however, seems sufficient to Williston to dismiss all the physiological aspect of Descartes's treatment of the conflicts of the soul. "Such conflict," he writes, "is not acratic because it is not properly speaking mental. It is conflict between a thought and the merely habitual movements of the body which are themselves manifested in characteristic ways in the disposition of spirits in the gland" (Williston 1999: 48). Williston's take on the problem, although extremely insightful and based on the correct assumption that Descartes was committed to ethical intellectualism, does not allow him to take into account, as a genuine expression of akratic behaviour, the fact that the mind can perceive, according to Descartes, the effects of simultaneous and opposed forces acting upon the pineal gland. Conversely, he contends that " $[\mathrm{t}]$ he two forces cannot $[\ldots]$ be simultaneously present to the mind," and consistently concludes that "strict acratic action is not possible" within Descartes's framework (Williston 1999: 47).

${ }^{23}$ CSM I, 338 / AT XI, 348-349. 
The perceptions that we refer only to the soul ${ }^{24}$ are those whose effects we feel as being in the soul itself, and for which we do not normally know any proximate cause to which we can refer them. Such are the feelings of joy, anger and the like, which are aroused in us sometimes by the objects which stimulate our nerves and sometimes also by other causes. ${ }^{25}$

As a consequence thereof, we are erroneously induced to admit the existence of different kinds of will, faculties, or appetites within a single thinking substance, in order to explain the simultaneous existence in our soul of perceptions that comply with our free willing and reasoning, and perceptions which we undergo and which seem instead to drive our will away from our deliberations. If we knew the real origin, or the "primary cause" of the passions in our soul, we would also know, as Descartes asserts in Article 51, "that the ultimate and most proximate cause of the passions of the soul is simply the agitation by which the spirits move the little gland in the middle of the brain." ${ }^{26}$ Hence, Descartes concludes:

So there is no conflict here except in so far as the little gland in the middle of the brain can be pushed to one side by the soul and to the other side by the animal spirits (which, as I said above, are nothing but bodies), and these two impulses often happen to be opposed, the stronger cancelling the effect of the weaker. ${ }^{27}$

\section{Mind-body interaction}

We see it clearly: what happens in the case of the so-called conflicts of the soul, in Descartes' view, is that two opposing forces act simultaneously upon a single extended object—namely, our pineal gland. On the one hand, our pineal gland moves according to the activity of our soul; on the other hand, our pineal gland also receives the movements transmitted by our bodily activity, through the flowing of the animal spirits into our brain. As Descartes states, "these two impulses often happen to be opposed, the stronger cancelling the weaker."

24 These "perceptions that we refer only to the soul" are what Descartes properly defines as the "passions of the soul" in his Treatise.

25 CSM I, 337-338 / AT XI, 347-348.

26 CSM I, 349 / AT XI, 371.

27 CSM I, 346 / AT XI, 365. 
Now, it seems evident that, in order to be tenable, Descartes' conclusion requires an account of how the soul and the body can interact and affect each other through another body-i.e., the pineal gland. How can the soul, that is, a substance with no extension (hence, with no shape, no mass, and no speed, amongst the other properties), exert any force upon a body? How can this force, originating from the soul, be commensurate with a certain quantity of movement and be applied to an extended thing? And, further, how can the force of our soul and the mechanic impulses originating in the body be opposed to each other, eventually cancelling the effects of each other?

Descartes' theory of mind-body interaction has always raised a lot of eyebrows, and I do not mean to defend it against its many critiques-amongst whom we may count, to begin with, Pierre Gassendi, ${ }^{28}$ Princess Elizabeth of Bohemia, ${ }^{29}$ and Henry More. ${ }^{30}$ In the rest of my paper, I will limit myself to providing an accurate exposition of Descartes' argument for the mind-body interaction, as it unfolds in his Passions of the Soul, with the purpose to clarify how Descartes relocates the problem of the weakness of the will from the traditional psychological domain to the physiological domain, in order to defend the essential unity of our soul. To achieve this goal, as we have seen, Descartes describes the so-called conflicts of the soul as the effect of the simultaneous action of two different substances upon a single part of the body. I would start, therefore, by recalling what Descartes states at the beginning of the Passions of the Soul, as to what we should understand as "action" and "passion." In the first Article of the Treatise, Descartes writes:

What is a passion with regard to one subject is always an action in some other regard. [...] Whatever takes place or occurs is generally called by philosophers a "passion" with regard to the subject to which it happens and an "action" with regard to that which makes it happen. Thus, although an agent and patient are often quite different, an action and passion must always be a single thing which has these two names on account of the two different subjects to which it may be related. ${ }^{31}$

28 CSM II, 235-237 / AT VII, 339-341.

${ }^{29}$ AT III, 661.

30 AT V, 385. For a brief, yet insightful summary of these criticisms, see Tollefsen 1999. For more general remarks on the various lines of criticism of Descartes's account of mindbody interaction, see M. D. Wilson, Descartes, New York: Routledge, 2005, 180-193. See also L. Shapiro, “Descartes's Passions of the Soul,” Philosophy Compass 1, 3, 2006, 271.

31 CSM I, 328 / AT XI, 327-328. 
This premise, which opens the whole Treatise on the Passions, seems to me to be intended also to support Descartes' thesis of the mind-body interaction. According to this thesis, we will see, all spontaneous actions of the body, insofar as they are transmitted to our soul through the movement of the pineal gland, occur to be passions in the soul. Through the pineal gland, the soul perceives the effect of the autonomous activity of the body and, in this sense, we may say that the body acts upon the soul, by acting upon the pineal gland. Conversely, all actions and volitions of the mind, insofar as they entail a corresponding movement by the pineal gland, are transmitted to the body, so that our volitions can be called passions in the body.

What is important to note here is that in the case of the so-called conflicts of the soul—which, as we have seen, are really to be understood as conflicts in the body-we must consider two agents acting simultaneously upon a single patient. Both the soul and the body can exert their force upon the pineal gland with the possibility of causing a clash, which is represented in the mind as a conflict where free will and reason, on the one hand, are opposed to bodily drives and appetites, on the other hand. To understand how this may happen, we have to analyse how the human body and soul can act autonomously and independently from each other, and how their respective autonomous activities can oppose each other if simultaneously applied to the movements of the pineal gland. First, I will focus on the autonomy, or spontaneity of the human body. Then, I will focus on the union of body and soul. Finally, I will comment on the freedom of the mind, in order to draw my conclusions.

\section{The autonomy of the human body}

Descartes stresses several times that the human body can be conceived of as an autonomous machine, and that there exists a spontaneous activity of the body, not requiring the presence of any spiritual principle in order to be able to perform itself. Articles 4 to 6 of the Passions of the Soul are devoted to this topic, ${ }^{32}$ but we can find the same thesis also expressed in the incipit and conclusion of his Treatise on Man. ${ }^{33}$

32 CSM I, 329-330 / AT XI, 329-331.

33 CSM I, 99 / AT XI, 120; CSM I, 108 / AT XI, 202: "I should like you to consider that these functions follow from the mere arrangement of the machine's organs every bit as naturally as the movements of a clock or other automaton follow from the arrangement of its counter-weights and wheels. In order to explain these functions, then, it is not necessary to conceive 
As to the "mechanism of our body," as Descartes calls it, he is convinced that our body is so composed that each modification in our nervous system, through the flow of the animal spirits towards the brain, modifies the position of the pineal gland, which is located at the centre of the brain. Vice-versa, each modification of the position of the pineal gland modifies in turn the flow of the animal spirits from the brain towards one or another part of the body, producing brain activity and local muscular movements. We can find the description of this "mechanism of our body" in Article 16 of the Passions of the Soul, notably entitled "How all the limbs can be moved by the objects of the senses and by the spirits without the help of the soul," ${ }^{4}$ and-as to the central role of the pineal gland-in Article 31 of the same text. ${ }^{35}$

\section{The union of mind and body}

Let us move now to the union of the body and the mind. Descartes claims that our mind is of such a nature that it perceives all the modifications that are mechanically produced in our pineal gland by the activity of our body, and that each modification of the position of the pineal gland corresponds to a perception in the soul. As he writes in Article 34 of the Passions of the Soul, the nature of the soul "is such that it receives as many different impressions - that is, it has as many different perceptions — as there occur different movements in this gland." 36

By this passage, I assume, Descartes is restating his theory of the "Natural Institution" - as Margaret Wilson suggestively called it. ${ }^{37}$ We may find traces of this theory in Descartes' Optics, for example, when he writes that "it is ordained

of this machine as having any vegetative or sensitive soul or other principle of movement and life, apart from its blood and its spirits, which are agitated by the heat of the fire burning continuously in its heart - a fire which has the same nature as all the fires that occur in inanimate bodies."

34 CSM I, 335 / AT XI, 341-342: "Every movement we make without any contribution from our will — as often happens when we breathe, walk, eat and, indeed, when we perform any action which is common to us and the beasts - depends solely on the arrangement of our limbs and on the route which the spirits, produced by the heat of the heart, follow naturally in the brain, nerves and muscles. This occurs in the same way as the movement of a watch is produced merely by the strength of its spring and the configuration of its wheels."

35 CSM I, 340 / AT XI, 352.

36 CSM I, 341 / AT XI, 355.

37 See M. D. Wilson, Descartes..., 182-191. Her analysis sheds much light on the problematic aspects of this theory in Descartes's works. 
by Nature" that our soul perceives the objects according to the way in which the nervous system modifies the brain. ${ }^{38}$ However, the most complete formulation of this theory is found in the Sixth Meditation. There, we shall see, Descartes' theory of mind-body interaction does not rely on any separate analysis as to how mutual causation can result from different substances. Rather, this interaction between different substances, and the subsequent correspondence between psychological and physiological states, is an effect which can only be understood within a theological framework — as a fact due to God's infinite goodness, good will, and absolute power ${ }^{39}$ - and then be corroborated by common everyday experience.

Any given movement occurring in the part of the brain that immediately affects the mind produces just one corresponding sensation; and hence the best system that could be devised is that it should produce the one sensation which, of all possible sensations, is most especially and most frequently conducive to the preservation of the healthy man. And experience shows that the sensations which nature has given us are all of this kind; and so there is absolutely nothing to be found in them that does not bear witness to the power and goodness of God. For example, when the nerves in the foot are set in motion in a violent and unusual manner, this motion, by way of the spinal cord, reaches the inner parts of the brain, and there gives the mind its signal for having a certain sensation, namely the sensation of a pain occurring in the foot. This stimulates the mind to do its best to get rid of the cause of the pain, which it takes to be harmful to the foot. It is true that God could have made the nature of man such that this particular motion in the brain indicated something else to the mind; it might, for example, have made the mind aware of the actual motion occurring in the brain, or in the foot, or in any of the intermediate regions; or it might have indicated something else entirely. ${ }^{40}$

According to this paragraph, it is only because of God's perfection, which entails supreme goodness, ${ }^{41}$ that certain physiological states happening within our

38 CSM I, 169 / AT VI, 134-135. In Descartes' Passions of the Soul, see Articles 36 and 50: "By entering into these pores [the spirits] produce in the gland a particular movement which is ordained by nature to make the soul feel this passion" (CSM I, 342 / AT XI, 357); "Words produce in the gland movements which are ordained by nature to represent to the soul only the sounds of their syllables when they are spoken or the shape of their letters when they are written" (CSM I, 348 / AT XI, 369).

39 Were it not for its theological and finalistic foundation, based on God's love towards humans, we may regard the natural correspondence of psychological and physiological states in Descartes as a "brute fact," to employ Michael Della Rocca's terminology (see, in this regard, M. Della Rocca, "PSR"...).

40 CSM II, 60-61 / AT VII, 87-88.

${ }^{41}$ See, for example, CSM II, 37-38 / AT VII, 53-54. 
body correspond to certain mental states happening within our mind, as we can experience in everyday life. ${ }^{42}$ If God had chosen otherwise, there would be no such correspondence, or it would be different by nature. ${ }^{43}$ As a consequence of God's goodness and will, therefore, insofar as they produce impressions and modifications in the pineal gland by triggering our nervous system, the soul perceives external objects, some biological functions, and some movements of the body. ${ }^{44}$ In this sense, according to Descartes, the body acts upon the mind, inducing thoughts in it, as it were, through the movements of the pineal gland.

\section{The activity of the soul}

As to the activity of the soul, Descartes holds it as evident that our mind can be conceived separately from the body to which it is joined, that it is free, and that, except for the perceptions that it passively receives from the activity of the body, it can lead its thoughts autonomously. For example, in Article 39 of his Principles of Philosophy, Descartes affirms that the freedom of our will "is so evident that it must be counted among the first and most common notions that are innate in us." ${ }^{45}$ In Article 41 of the Passions of the Soul he also writes:

${ }^{42}$ As evasive as it may sound, this argument is interesting insofar as it seems aimed at disposing of the problems ensuing from the claim of a direct causation between substances of a different nature. In fact, Descartes seems willing to accept that no spiritual activity or idea can be deduced from, or associated with the moving of a body, without further explanation. Indeed, Descartes argues, only a supremely powerful and good being can have ordered the things in such way, by disposing the human mind to perceive certain representations and passions "on the occasion" of certain bodily dispositions (for references in Descartes's works concerning a similar employment of the controversial expressions "on the occasion" and "to give the occasion," see, for example, the First Chapter of The World [CSM I, 82 / AT XI, 5-6], his Treatise on Man [CSM I, 102-103 / AT XI, 143-144; CSM I, 106 / AT XI, 176], his Optics [CSM I, 166 / AT VI, 114], his Sixth Replies [CSM II, 295 / AT VII, 437], and his Comments on a Certain Broadsheet [CSM I, 304 / AT VIII B, 359]). This argument also provides Descartes with the means to contend that ordinary observations around the union of the mind and body cannot help but confirm the attributes of God that can be deduced by considering only its innate idea—such as its supreme perfection, power, and goodness.

43 This could include the case of a possibly "deceiving God."

${ }^{44}$ CSM I, 337 / AT XI 346-347.

45 CSM I, 205-206 / AT VIII A, 19. 
The will is by its nature so free that it can never be constrained. Of the two kinds of thought I have distinguished in the soul - the first its actions, i.e. its volitions, and the second its passions, taking this word in its most general sense to include every kind of perception - the former are absolutely within its power and can be changed only indirectly by the body, whereas the latter are absolutely dependent on the actions which produce them, and can be changed by the soul only indirectly, except when it is itself their cause. And the activity of the soul consists entirely in the fact that simply by willing something it brings it about that the little gland to which it is closely joined moves in the manner required to produce the effect corresponding to this volition. ${ }^{46}$

Thus, by freely thinking, the mind can also operate upon and along with its body. Thoughts produced by the free will of our soul must in fact correspond to precise modifications in the position of the pineal gland, according to the Natural Institution decreed by God. These movements of the pineal gland trigger in turn mechanical reactions in our nervous system and consequent movements in our body. Therefore, since the gland assumes the position corresponding to an individual's volitions each time,${ }^{47}$ voluntary movement in the

46 CSM I, 343 / AT XI, 359-360.

${ }^{47}$ It is to be noted that Descartes takes good care in delimiting the potentially infinite range of this claim, to avoid absurd consequences being deduced from it. As we have seen from Descartes's argument in the Sixth Meditation, the perceptions or ideas joined to the various positions or movements of the pineal gland, according to God's Natural Institution, are only those which are more useful to the preserving of the body. Conversely, not all possible volitions that a mind can imagine are in fact joined to a movement or a position of the gland. See, for example, Article 44 of the Passions of the Soul: "Our volition to produce some particular movement or other effect does not always result in our producing it; for that depends on the various ways in which nature or habit has joined certain movements of the gland to certain thoughts. For example, [...] the movement of the gland, whereby the spirits are driven to the optic nerve in the way required for enlarging or contracting the pupils, has been joined by nature with the volition to look at distant or nearby objects, rather than with the volition to enlarge or contract the pupils" (CSM I, 344 / AT XI, 361-362). Now, Descartes's references to human habits, conceived of as an alternative source of mind-body states correspondence might appear potentially destructive for the Natural Institution theory; or, at least, they may suggest a "subtle shift" from the position he held in the Sixth Meditation, as pointed out by L. Shapiro, "Descartes's Passions of the Soul"..., 272. In the Passions of the Soul Descartes seems to try to avoid the problem by recurring to his theory of memory, understood as a kind of plasticity of the body (see the Article 42 of the Passions of the Soul, CSM I, 343-344 / AT XI, 360). Whereas the mind can do nothing to change the order according to which God has joined certain perceptions to certain bodily states, the passions associated with those perceptions can be changed in favour to others, on the basis of past experiences. 
body is produced as an effect. In this sense, Descartes asserts, the soul acts upon the body, by "pushing" and "moving" the pineal gland. ${ }^{48}$

\section{Natural institution and indirect action}

According to the passages I cited from Descartes' works, the union between the human mind and body can be simply denoted as a mutual and necessary correspondence existing between some thoughts in the mind and some movements of the pineal gland in the body, instituted by nature according to God's masterplan. It is because of this constant correspondence of bodily and mental states, provided the body and the mind can act autonomously and independently from each other, that they can eventually act upon each other and be acted upon by each other, simultaneously. Despite the appearances, I am persuaded that with this theory Descartes is not proposing a naïve solution to the mind-body interaction problem. For-as Descartes states clearly in Article 41 above quoted - the action of one substance upon the other cannot be a direct action. Very simply put, mind-body interaction cannot be understood as a sort of psychokinetic power, as it were.

"Each volition is naturally joined to some movement of the gland," Descartes writes in Article 44 of the Passions of the Soul. ${ }^{49}$ What we have to maintain

For example, through the aid of memory, the mind can remember courage and act with courage when it perceives fear, and respond with love to the hate it may feel. When a behavioural pattern of such sort permanently modifies the corporeal cavities through which the spirits flow after a certain external object is perceived, the passion associated to the perception of an object is modified accordingly. See, in this regard, Articles 36, 45, 46, and 50 of Descartes' Passions of the Soul (CSM I, 342 / AT XI, 362-364; CSM I, 345 / AT XI, 356-357; CSM I, 348 / AT XI 368-369).

48 See Article 34 of Descartes' Passions of the Soul: "The small gland which is the principal seat of the soul is suspended within the cavities containing these spirits, so that it can be moved by them in as many different ways as there are perceptible differences in the objects. But it can also be moved in various different ways by the soul, whose nature is such that it receives as many different impressions - that is, it has as many different perceptions as there occur different movements in this gland. And conversely, the mechanism of our body is so constructed that simply by this gland's being moved in any way by the soul or by any other cause, it drives the surrounding spirits towards the pores of the brain, which direct them through the nerves to the muscles; and in this way the gland makes the spirits move the limbs" (CSM I, 341 / AT XI, 354-355).

49 CSM I, 344 / AT XI, 361. 
here, according to Descartes' Natural Institution theory, is just the strict correspondence that necessarily exists between certain mental states, on the one hand, and certain bodily states, on the other hand..$^{50}$ For we shall not overlook that, according to Descartes, the only activity that we may attribute to the soul is the thinking (that is, to perceive and to will things), whereas the only activity pertaining to a body is movement in space. ${ }^{51}$ Moreover, as Descartes adds in the Passions of the Soul, the soul does not know how the body machinery works, and it totally ignores how the pineal gland shall be moved in order for the body to perform certain actions. ${ }^{52}$ As a matter of fact, the soul only represents to itself those actions it wants the body to perform, as objects of its volitions: "as when our merely willing to walk," Descartes writes in Article 18 of the Passions of the

${ }^{50}$ It is better to recall that Descartes holds this correspondence between bodily states and thoughts as self-evident, inasmuch as we cannot fail to experience it in our everyday life. As he writes in a letter to Arnauld, "[t]hat the mind, which is incorporeal, can set the body in motion is something which is shown to us not by any reasoning or comparison with other matters, but by the surest and plainest everyday experience" (CSMK, 358 / AT V, 222). In another letter, addressed to Elizabeth, Descartes lists the union between the mind and the body amongst the primitive notions of knowledge: "I consider that there are in us certain primitive notions which are as it were the patterns on the basis of which we form all our other conceptions. There are very few such notions. First, there are the most general-those of being, number, duration, etc.-which apply to everything we can conceive. Then, as regards body in particular, we have only the notion of extension, which entails the notions of shape and motion; and as regards the soul on its own, we have only the notion of thought, which includes the perceptions of the intellect and the inclinations of the will. Lastly, as regards the soul and the body together, we have only the notion of their union, on which depends our notion of the soul's power to move the body, and the body's power to act on the soul and cause its sensations and passions" (CSMK, 218 / AT III, 665).

51 See, for example, Descartes' Principles of Philosophy I, $\$ 8-9$ and 32 (CSM I, 195 / AT VIII A, 7-8; CSM I, 204 / AT VIII A, 17), and Principles of Philosophy II, \$23 (CSM I, 232-233 / AT VIII A, 52-53).

52 Emanuela Scribano argues that this claim is also at the origin of some later occasionalist developments of the mind-body interaction theory, such as those found in Arnold Geulicx and Nicolas Malebranche. According to Scribano, both Geulincx and Malebranche maintained within a Cartesian framework the "epistemic condition of causality," that is, a principle according to which "it is necessary to be aware of the means by which an effect is produced to be able to produce it" (in Latin, "quod nescis quomodo fiat, id non facis." See J. P. N. Land, Arnoldi Geulincx Antverpiensis Opera Philosophica, Vol. 3, The Hague: Martinum Nijhoff, 1891-1893, 205-206). The origin of this principle, Scribano contends, can be traced back to Galen's works on human anatomy and the formation of the human foetus. Traces of the same principle can also be found in Tommaso Campanella and Pierre Chanet. See, in this regard, E. Scribano, "Quod nescis quomodo fiat, id non facis. Occasionalism against Descartes?,” Rinascimento 51, 2011, 63-86. 
Soul, "has the consequence that our legs move and we walk." ${ }^{3}$ The same concept is also stressed in a letter to Elizabeth:

There is no doubt that the soul has great power over the body, as is shown by the great bodily changes produced by anger, fear and the other passions. The soul guides the spirits into the places where they can be useful or harmful; however, it does not do this directly through its volition, but only by willing or thinking about something else. For our body is so constructed that certain movements in it follow naturally upon certain thoughts: as we see that blushes accompany shame, tears compassion, and laughter joy. ${ }^{54}$

Descartes' treatment of the so-called "conflicts of the soul" clarifies and confirms this aspect of his theory - that is, that the way in which the mind and body act upon each other can only be indirect. Hence, Descartes concludes in Article 47 of the Passions of the Soul that we have been analysing so far by writing:

Such a conflict is revealed chiefly through the fact that the will, lacking the power to produce the passions directly [...], is compelled to make an effort to consider a series of different things, and if one of them happens to have the power to change for a moment the course of the spirits, the next one may happen to lack this power, whereupon the spirits will immediately revert to the same course because no change has occurred in the state of the nerves, heart and blood. This makes the soul feel itself impelled, almost at one and the same time, to desire and not to desire one and the same thing; and that is why it has been thought that the soul has within it two conflicting powers. ${ }^{55}$

To conclude, according to Descartes, the proximate cause of what we usually regard as conflicts in our soul—when the force of our passions, that is, seems to prevent us from following our free judgements, will and deliberations-is the upshot of a quite complex physiological activity, of which we perceive the effects in our mind. Because of our bodily constitution, it may naturally happen that the impression of an external object on the pineal gland causes our nervous system to react and dispose our body to execute certain movements. This reaction, in turn, may trigger a sort of neural feedback that, passing through the heart,

53 CSM I, 335 / AT XI, 343.

${ }^{54}$ CSMK, 237 / AT V, 65.

55 CSM I, 346 / AT XI, 365-366. 
reinforces the pineal gland in its position and the body in its disposition. ${ }^{56}$ Through the pineal gland, the soul perceives this natural inclination of the body to act autonomously in some determinate ways, and regards it as a sort of involuntary will and appetite. ${ }^{57}$

Descartes provides the example of our natural and almost unstoppable inclination to run away at the sight of terrifying things. ${ }^{58}$ This is a purely physiological mechanism though, and the soul cannot do anything to prevent it - it just perceives it. ${ }^{59}$ The only way in which the soul can limit (and eventually halt) the effects ensuing from this spontaneous activity of its body, is by the only power of which it is capable: that is, to employ its freedom of thinking and focus on states of mind that can indirectly induce physiological reactions, contrary and opposed to those caused by the passions themselves. ${ }^{60}$ If the soul succeeds in this endeavour-that is, if the soul sticks to its thoughts, as it were, concentrating on its volitions and deliberations despite the stream of appetites brought about by the passions-, then the pineal gland will naturally and necessarily assume the position corresponding to the individual's new mental attitude, causing as a consequence a flow of spirits into the body that will naturally oppose those generated by the passions. ${ }^{61}$ In this sense, according to Descartes, the conflicts that see the soul opposed to the automatisms of the body, in order to get control over the body, reveal the strength or the weakness of one's soul. ${ }^{62}$ This claim works as a reply and a solution to the problem from which we departed, that is, the existence of akrasia. Without denying its existence, self-aware akratic conduct can be understood, on

56 Descartes describes this physiological process in Articles 36-38 of his Passions of the Soul (CSM I, 342-343 / AT XI, 356-358).

57 CSM I, 343 / AT XI, 359.

58 CSM I, 342 / AT XI, 356-357.

59 CSM I, 342-343 / AT XI, 358.

${ }^{60}$ CSM I, 345 / AT XI, 362-363.

${ }^{61}$ Williston's remarks on the importance of the withdrawal of attention in determining one's akratic behaviour are very significant in this sense. Yet, he does not seem to me to sufficiently consider the physiological mechanism on which attention is based, in Descartes. Our capability of paying attention to things is in fact subject to the same forces which act upon the pineal gland (Descartes hints at this mechanism in the Article 43 of his Passions of the Soul, CSM I, 344 / AT XI, 361). As a consequence, Williston assimilates the withdrawal of attention to a kind of self-deception (B. Williston, "Akrasia and the passions in Descartes," British Journal for the History of Philosophy 7, 1, 1999, 46).

${ }^{62}$ CSM I, 347 / AT XI, 366-367. 
Descartes' account, as a conflict arising from the interaction of two substances joined in an extended spot, leaving at least one of the two substances-i.e., the individual soul — united in its nature.

However, Descartes also holds that the proper instruments of a strong soul are "firm and determinate judgements bearing upon the knowledge of good and evil," and that "[t]he strength of the soul is not enough without the knowledge of truth." ${ }^{63}$ Once again, we see, the "weapons" with which the soul can indirectly act upon the body and tackle the passions are purely spiritual, and exclude any direct contact between different substances. Experience teaches us in fact that the more the arguments that accompany the resolutions of our will are sound and adherent to the truth, the more the mind is capable of sticking to its thoughts and purposes, and the less it is distracted by less important perceptions, desires and appetites that may come to its attention through the body. Well-founded arguments can also quell appetites that are harmful to our well-being, by providing good reasons to perform different actions. ${ }^{64}$ Therefore, the train of thought of a well-thinking mind, Descartes suggests, adheres by its own strength to the free deliberations of the soul and is less dependent on perceptions and drives coming from the body. This may happen, as we have seen, because the movements of the pineal gland must match, by natural institution of God, the actual states of mind. Therefore, when the soul endeavours to reason, the movements of the gland and the body's ensuing activity will adhere more closely to the dictates of the soul that originates from the power of the soul alone considered, and will oppose more resistance to the forces acting on the gland through stimuli coming from the external world.

This final assumption, united with the belief that the soul can always combine its absolute freedom of thinking with the solidity of clear and distinct reasoning, leads Descartes to claim optimistically, at the end of the First Part of The Passions of the Soul, that "[t]here is no soul so weak that it cannot, if well-directed, acquire an absolute power over its passions." ${ }^{65}$ In this way, Descartes ends up defending both the unity of the soul and the ethical intellectualism against Plato's theory of the partitioned soul, while arguing at the same time for the possibility of akratic behaviour in humans.

63 CSM I, 347 / AT XI, 367.

${ }^{64}$ See Articles 45 and 49 of Descartes's Passions of the Soul (CSM I, 345 / AT XI, 362-363; CSM I, 347 / AT XI, 367-368).

65 CSM I, 348 / AT XI, 368. 


\section{References}

Adam, C., and P. Tannery (eds.), Euvres De Descartes, Vol. 13, Paris: Léopold Cerf, 18971913.

Annas, J., An Introduction to Plato's Republic, Oxford: Clarendon Press, 1981.

Bobonich, C., "Akrasia and Agency", in: Plato, Laws and Republic. Essays on Plato's Psychology, ed. E. Wagner, Lanham: Lexington Books, 2001, 203-237. [Archiv für Geschichte der Philosophie 76, 1994, 3-36].

Burnyeat, M. F., "Plato on the Grammar of Perceiving," Classical Quarterly 26, 1976, 29-51.

Cottingham, J., R. Stoothoff, and D. Murdoch (trans.), The Philosophical Writings of Descartes, Vol. 2, Cambridge: Cambridge University Press, 1984.

Cottingham, J., R. Stoothoff, D. Murdoch, and A. Kenny (trans.), The Philosophical Writings of Descartes, Vol. 3: The Correspondence, Cambridge: Cambridge University Press, 1991.

D’Arcy, P. (ed.), Descartes. Les passions de l'âme, Paris: Flammarion, 1996.

Della Rocca, M., “PSR,” Philosophers' Imprint, 10, 7, 2010, 1-13.

Frede, M., "Introduction," in: Plato, Protagoras, ed. and trans. S. Lombardo \& K. Bell, Indianapolis/Cambridge: Hackett, 1992, vII-XXXII.

Grube, G. M. A., and C. D. C. Reeve (trans.), Republic, in: Plato Complete Works, ed. J. M. Cooper and D. S. Hutchinson, Indianapolis/Cambridge: Hackett, 1997, 971-1223.

Irwin, T., Plato's Ethics, Oxford: Oxford University Press, 1995.

Land, J. P. N., Arnoldi Geulincx Antverpiensis Opera Philosophica, Vol. 3, The Hague: Martinum Nijhoff, 1891-1893.

Miller, Fred D. Jr., "Plato on the Parts of the Soul," Plato and Platonism, ed. J. Max van Ophuijsen, Washington: The Catholic University Press of America, 1999, 84-101.

Moline, J., "Plato on the Complexity of the Psyche," in: Archiv für Geschichte der Philosophie, 60, 84-101, 1-26.

Moline, J., Plato's Theory of Understanding, Madison: The University of Wisconsin Press, 1981.

Nehamas, A., and P. Woodroof (trans.), Phaedrus. Plato Complete Works, ed. J. M. Cooper and D. S. Hutchinson, Indianapolis/Cambridge: Hackett, 1997, 506-556.

Rozemond, M., "The Faces of Simplicity in Descartes's Soul," Partitioning the Soul: Debates from Plato to Leibniz, ed. K. Corcilius and D. Perler, Berlin/Boston: Walter de Gruyter, 2014, 219-253.

Scribano, E., "Quod nescis quomodo fiat, id non facis. Occasionalism against Descartes?," Rinascimento 51, 2011, 63-86.

Shapiro, L., "Descartes's Passions of the Soul," Philosophy Compass 1, 3, 2006, 268-278.

Shields, C., "Plato's Divided Soul," Partitioning the Soul: Debates from Plato to Leibniz, ed. K. Corcilius and D. Perler, Berlin/Boston: Walter de Gruyter, 2014, 15-38. [Plato, Republic: A Critical Guide, ed. M. L. McPherran, Cambridge: Cambridge University Press, 2010, 147-170].

Shields, C., "Unified Agency and Akrasia, in: Plato, Republic, "Akrasia." Greek Philosophy: From Socrates to Plotinus, ed. C. Bobonich and P. Destrée, Leiden/Boston: Brill, 2007, 61-86. 
Tollefsen, D., "Princess Elisabeth and the Problem of Mind-Body Interaction," in: Hypatia 14, 3, 1999, 59-77.

Williston, B., "Akrasia and the passions in Descartes," British Journal for the History of Philosophy, 7, 1, 1999, 33-55.

Wilson, M. D., Descartes, New York: Routledge, 2005. [Boston: Routledge and Kegan Paul, 1978]. 